\title{
Tissue-specific expression of high-voltage-activated dihydropyridine-sensitive L-type calcium channels
}

\author{
Martin BIEL ${ }^{1,2}$, Roger HULLIN ${ }^{1,2}$, Stefanie FREUNDNER ${ }^{1}$, Dafna SINGER ${ }^{3}$, Nathan DASCAL ${ }^{3}$, Veit FLOCKERZI $^{1}$ \\ and Franz HOFMANN ${ }^{2}$ \\ 1 Institut für Medizinische Biochemie, Medizinische Fakultät, Universität des Saarlandes, Homburg, Federal Republic of Germany \\ 2 Institut für Pharmakologie und Toxikologie, Technische Universität München, Federal Republic of Germany \\ ${ }^{3}$ Sackler School of Medicine, Department of Physiology and Pharmacology, Tel Aviv University, Israel
}

(Received February 11 / April 26, 1991) - EJB 910210

The cloning of the cDNA for the $\alpha_{1}$ subunit of L-type calcium channels revealed that at least two genes ( $\mathrm{CaCh} 1$ and $\mathrm{CaCh} 2$ ) exist which give rise to several splice variants. The expression of mRNA for these $\alpha_{1}$ subunits and the skeletal muscle $\alpha_{2} / \delta, \beta$ and $\gamma$ subunits was studied in rabbit tissues and $\mathrm{BC}_{3} \mathrm{H} 1$ cells. Nucleic-acidhybridization studies showed that the mRNA of all subunits are expressed in skeletal muscle, brain, heart and aorta. However, the $\alpha_{1^{-}}, \beta$ - and $\gamma$-specific transcripts had different sizes in these tissues. Smooth muscle and heart contain different splice variants of the $C a C h 2$ gene. The $\alpha_{1}, \beta$ and $\gamma$ mRNA are expressed together in differentiated but not in proliferating $\mathrm{BC}_{3} \mathrm{H} 1$ cells. A probe specific for the skeletal muscle $\alpha_{2} / \delta$ subunit did not hybridize to poly(A)-rich RNA from $\mathrm{BC}_{3} \mathrm{H} 1$ cells. These results suggest that different splice variants of the genes for the $\alpha_{1}$, $\beta$ and $\gamma$ subunits exist in tissues containing L-type calcium channels, and that their expression is regulated in a coordinate manner.

Voltage-activated calcium channels comprise a group of very similar yet distinct proteins or protein complexes that differ in electrophysiological properties, modulation by phosphorylation and guanosine-nucleotide-binding regulatory proteins, and in their relative sensitivity to organic-calciumchannel blockers [ $1-4]$. The principal transmembrane subunit of an L-type calcium channel is the receptor for calcium channel blockers or $\alpha_{1}$ subunit, and when purified from rabbit skeletal muscle this protein $(165 \mathrm{kDa})$ is associated with a $55-$ $\mathrm{kDa}$ protein $(\beta)$, a $32-\mathrm{kDa}$ protein $(\gamma)$ and a disulfide-linked dimer of $130 / 28 \mathrm{kDa}\left(\alpha_{2} / \delta\right)[5-8]$. The primary structures of the $\alpha_{1}[9-11], \alpha_{2} / \delta[10,12], \beta[13]$ and $\gamma$ proteins $[14,15]$ have been deduced by cloning their cDNA and $\alpha_{1}$-like proteins have been identified in a variety of tissues from different species on the basis of sequence homology with their skeletal muscle counterpart [16-23].

However, only the expression of full-length cDNA of the $\alpha_{1}$ subunits from rabbit heart [16] and lung [17] in Xenopus laevis oocytes results in dihydropyridine-sensitive calcium

Correspondence to V. Flockerzi, Institut für Medizinische Biochemie, Medizinische Fakultät, Universität des Saarlandes, W-6650 Homburg, Federal Republic of Germany

Abbreviations. (+)PN200-110, (+)-isopropyl-4-(2,1,3-benzoxadiazol-4-yl)-1,4-dihydro-2,6-dimethyl-5-methoxycarbonylpyridine3-carboxylate; PCR, polymerase chain reaction; $\mathrm{CaCh} 1$, rabbit skeletal muscle calcium channel $\alpha_{1}$ subunit; $\mathrm{CaCh} 2 \mathrm{~A}$, rabbit heart calcium channel $\alpha_{1}$ subunit; CaCh2B, rabbit lung calcium channel $\alpha_{1}$ subunit.

Enzymes. T4 DNA Ligase (EC 6.5.1.1); reverse transcriptase (EC 2.7.7.49); DNA polymerases, Klenow enzyme, sequenase (EC 2.7.7.7); SP6 RNA polymerase (EC 2.7.7.6), alkaline phosphatase (EC 3.1.3.1); type II restriction endonucleases (EC 3.1.21.4). channels. The transient expression of the skeletal muscle $\alpha_{1}$ subunit in myoblasts from dysgenic mice [24] is complicated by the presence of endogenous $\mathrm{Ca}^{2+}$ currents. Its expression in murine L-cells [11] leads to the appearance of a dihydropyridine-sensitive $\mathrm{Ca}^{2+}$ current, which activates about ten times slower than $\mathrm{Ca}^{2+}$ currents in skeletal muscle, and phenotypic cell lines of skeletal muscle, such as $\mathrm{BC}_{3} \mathrm{H} 1$ cells. The $\alpha_{2} / \delta$ and $\beta$ subunits are missing in murine L-cells [25] and it has been suggested that to acquire skeletal muscle properties, $\alpha_{1}$ must be associated with one or more of the other subunits. In this case a common regulatory mechanism controlling the expression of calcium channel $\alpha_{1}$ subunits and other $\alpha_{2} / \delta-, \beta$ and $\gamma$-like proteins might exist, and mRNA for all subunits should be present in cells containing functional L-type calcium channels. Therefore, in this investigation, the expression of $\alpha_{1}, \alpha_{2} / \delta, \beta$ and $\gamma$ mRNA was studied in parallel by blot hybridization analysis using poly(A)-rich RNA from various rabbit tissues and $\mathrm{BC}_{3} \mathrm{H} 1$ cells, as well as subunit-specific RNA probes. It is shown that splice variants of the genes for these subunits are expressed in each tissue, and that in $\mathrm{BC}_{3} \mathrm{H} 1$ cells only expression of the $\alpha_{1}, \beta$ and $\gamma$ mRNA, but not of $\alpha_{2} /$ $\delta$ mRNA, is regulated in a coordinate manner.

\section{MATERIALS AND METHODS}

\section{Materials}

${ }^{35} \mathrm{~S}$-labeled deoxyadenosine $[\alpha$-thio $]$ triphosphate $\left[{ }^{35} \mathrm{~S}\right]-$ dATP $(1.370 \mathrm{Ci} / \mathrm{mmol}),\left[\alpha-{ }^{32} \mathrm{P}\right] \mathrm{dCTP}(3.000 \mathrm{Ci} / \mathrm{mmol}),[\alpha-$ $\left.{ }^{32} \mathrm{P}\right] \mathrm{GTP} \quad(800 \mathrm{Ci} / \mathrm{mmol})$, (+)-isopropyl-4-(2,1,3-benzoxadiazol-4-yl)-1,4-dihydro-2,6-dimethyl-5-[ $\left.{ }^{3} \mathrm{H}\right]$ methoxycarbo- 
Table 1. Recombinant antisense constructs

\begin{tabular}{llllc}
\hline Soure & Plasmid & Subunit & $\begin{array}{l}\text { Antisense probe } \\
\text { positions }\end{array}$ & $\begin{array}{l}\text { Refer- } \\
\text { ence }\end{array}$ \\
\hline Skeletal & pCaA1a & $\alpha_{1}$ & $1006-5314$ & 9 \\
muscle & pCA2a & $\alpha_{2} / \delta$ & $2550-3528$ & 16 \\
& pCaB1a & $\beta$ & $-22-1608$ & 13 \\
& pCaG1a & $\gamma$ & $-48-680$ & 14 \\
Lung & pCaCa & $\alpha_{1}$ & $2199-4335$ & 17 \\
\multirow{2}{*}{ Heart } & pATL & $\alpha_{1}$ & $-118-32$ & 17 \\
& pATH & $\alpha_{1}$ & $-191-134$ & 16 \\
\hline
\end{tabular}

nylpyridine-3-carboxylate $(+)\left[{ }^{3} \mathrm{H}\right] \mathrm{PN} 200-110, \quad 85.9 \mathrm{Ci} /$ mmol] were purchased from DuPont-New England Nuclear. $\mathrm{CsCl}$ was from Gibco BRL Life Technologies. All enzymes were from Boehringer-Mannheim except Sequenase $\mathrm{II}^{\mathrm{TM}}$ and Taq polymerase which were from United States Biochemical $\mathrm{GmbH}$ and Perkin-Elmer GmbH, respectively. Guanidine isothiocyanate was from Fluka Chemie AG, salmon sperm DNA, polyvinylpyrrolidone and Ficoll were from Sigma Chemicals. Seakem GTG-agarose was from FMC Bioproducts. Bacto-agar, yeast extract and bacto-tryptone were from Difco. Glass-fiber filters GF/C were obtained from Whatman. All other chemicals were of the highest quality available.

\section{Methods}

RNA-blot-hybridization analysis. For the preparation of antisense RNA probes, seven recombinant plasmids were constructed carrying the SP6 promotor [26] and the nucleotide sequences of calcium channel subunits from skeletal muscle, lung and heart (Table 1). The skeletal muscle and lung sequences were obtained by subcloning the respective cDNA [9, $13,14,16,17]$. The full-length cardiac $\alpha_{1}$ cDNA was cloned using the nucleotide sequence of Mikami et al. [16]. Briefly, the XhoI - SphI fragment (the XhoI site is located in the oligodeoxynucleotide linker 5'-CCGCTCGAGGTCGAC - 3' attached to position -191 ; the fragment runs to position 1488) and the BspHI-SacII (positions 3553-4116) fragment of the cardiac $\alpha_{1}$ cDNA [16] obtained by polymerase chain reaction (PCR) amplification of a random-primed cDNA library from rabbit heart and the $S p h \mathrm{I}-B s p \mathrm{HI}$ (positions 1473-3542) fragment from pSCaL [17] were ligated with the $5.3-\mathrm{kb} X h o \mathrm{I}-$ SacII fragment from pSCaL [17] to yield the pSP72 recombinant plasmid pCaH. As in [16], the cloned cardiac cDNA induces the formation of a high-voltage-activated dihydropyridine-sensitive L-type calcium channel when expressed in Xenopus oocytes. The antisense RNA probes were synthesized in vitro with $\left[\alpha-{ }^{32} \mathrm{P}\right]$ GTP using the linearized plasmids as templates for transcription with SP6 polymerase. RNA-blotting analysis was carried out essentially according to [27] except that Biodyne nylon membranes (Pall) were used and that hybridization was performed at $65^{\circ} \mathrm{C}$ in the presence of $50 \%$ formamide and $0.5 \%$ SDS. For blot-hybridization analysis, total RNA was prepared from tissues of adult rabbits or from $\mathrm{BC}_{3} \mathrm{H} 1$ cells by the guanidinium thiocyanate method and poly(A)-rich RNA, as in [13, 14]. The yield of poly(A)rich RNA during oligo(dT)-cellulose chromatography was $5-7 \%$ for all preparations.

\section{Cell culture}

$\mathrm{BC}_{3} \mathrm{H} 1$ (ATCC 1443) cultures were grown in Dulbecco's modified Eagle's medium containing $20 \%$ fetal bovine serum,
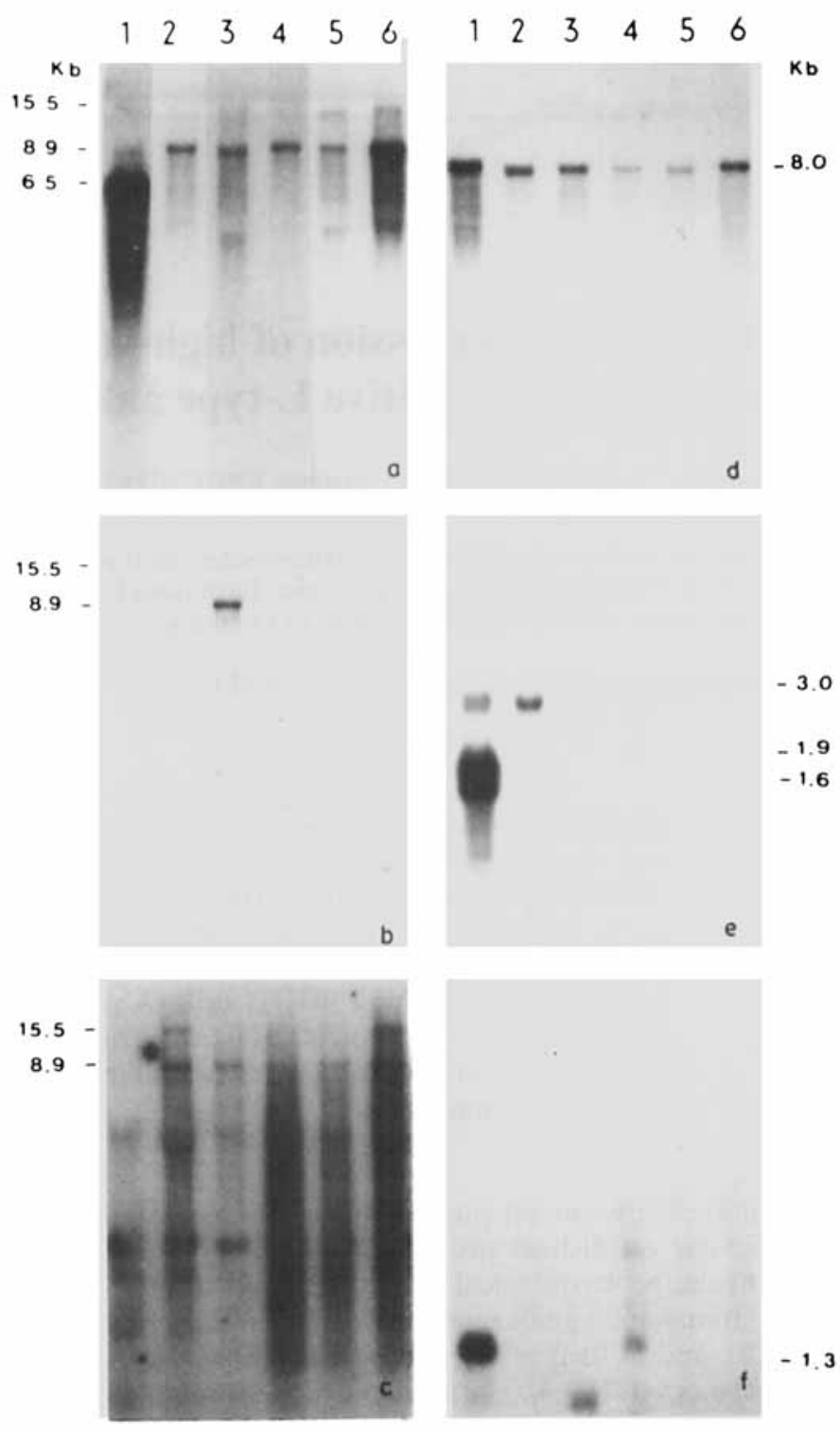

Fig. 1. Autoradiograms of blot hybridization analysis of poly $(A)$-rich $R N A$ from adult rabbit tissues. Samples of $10 \mu \mathrm{g}$ poly(A)-rich RNA from skeletal muscle (lane 1), brain (lane 2), heart (lane 3), aorta (lane 4), trachea (lane 5) and lung (lane 6) were electrophoresed on $1.2 \%$ agarose gels. Autoradiographic exposure was $16 \mathrm{~h}$ (a, lanes 2, 5 and 6 ; d, lanes $1-3$; b and $f$ ), 3 days (a, lanes 1,3 and $4 ; d$, lanes $4-6$; e) and 20 days (c). The size markers used were Escherichia coli rRNA and the RNA ladder purchased from Gibco BRL Life Technologies. The RNA probes used were specific for the $\alpha_{1}$ subunits from heart and lung (a), heart (b), lung (c) and for the skeletal muscle $\alpha_{2} / \delta$ (d), $\beta$ (e) and $\gamma$ (f) subunits. The specific activities of the six probes used were $0.8-2.2 \times 10^{9} \mathrm{dpm} / \mu \mathrm{g}$

penicillin $(100 \mathrm{U} / \mathrm{ml})$ and streptomycin $(100 \mu \mathrm{g} / \mathrm{ml})$, as described in [28]. The medium was changed every 2 days. To minimize differentiation, $\mathrm{BC}_{3} \mathrm{H} 1$ cells were passaged when no more than $60 \%$ confluent. P1-, P2-, and P3-designate proliferating $\mathrm{BC}_{3} \mathrm{H} 1$ cells were used which were $10-20 \%, 30-$ $50 \%$ and $60-80 \%$ confluent, respectively. Differentiation was induced by reduction of the fetal bovine serum concentration to $0.5 \%$. For binding assays and RNA preparation, cells were washed twice with Hanks' balanced salt solution, collected by scraping, sedimented and frozen at $-80^{\circ} \mathrm{C}$. 
Table 2. CaCh2A-derived [16] and CaCh2B-derived [17] oligodeoxynucleotide primers used for cDNA synthesis and PCR

\begin{tabular}{|c|c|c|c|}
\hline Primer & Sequence & Subunit & Positions \\
\hline 1 & $5^{\prime}$-GTGTTCAGGAAGACCAG-3' & $\mathrm{CaCh} 2 \mathrm{~B}$ & 1672 to 1688 \\
\hline 2 & $5^{\prime}$-TAAAACGTAAAGTATTACTAAAACCTC - $3^{\prime}$ & $\mathrm{CaCh} 2 \mathrm{~A}$ & -191 to -165 \\
\hline 3 & $5^{\prime}$-GCACTGCCCATCAGCTTG-3' & $\mathrm{CaCh} 2 \mathrm{~B}$ & 186 to 203 \\
\hline 4 & $5^{\prime}$-TGCGCCGCCTCGCTCTGTT-3' & $\mathrm{CaCh} 2 \mathrm{~B}$ & -312 to -294 \\
\hline 6 & $5^{\prime}$-CATGGGTCTCTGTGGAGTGACTAA-3' & $\mathrm{CaCh} 2 \mathrm{~B}$ & 1442 to 1467 \\
\hline
\end{tabular}

\section{$\left[{ }^{3} \mathrm{H}\right] \mathrm{PN} 200-110$ binding to $\mathrm{BC}_{3} \mathrm{Hl}$ cells}

Cell pellets were thawed in $5 \mathrm{mM}$ Tris $/ \mathrm{HCl}, \mathrm{pH} 7.4$ containing $0.1 \mathrm{mM}$ phenylmethylsulfonyl fluoride, $1 \mathrm{mM}$ phenanthroline, $100 \mathrm{mM}$ iodoacetamide, $1 \mathrm{mM}$ benzamidine, $1 \mu \mathrm{M}$ pepstatin $\mathrm{A}, 1 \mu \mathrm{g} / \mathrm{ml}$ antipain and $1 \mu \mathrm{g} / \mathrm{ml}$ leupeptin (protease inhibitor mix), homogenized and centrifuged at $1000 \mathrm{xg}$ for $20 \mathrm{~min}$. The supernatant was then centrifuged at $42000 \mathrm{xg}$ for $40 \mathrm{~min}$ at $4 \mathrm{C}$. The pellet was rehomogenized in $50 \mathrm{mM}$ Tris/ $\mathrm{HCl}$, pH 7.4 containing the protease inhibitor mix. Equilibrium binding of $(+)\left[{ }^{3} \mathrm{H}\right] \mathrm{PN} 200-110$ was performed as described previously [29] in the presence of $25 \mu \mathrm{g}$ protein and $1 \mathrm{nM}(+)\left[{ }^{3} \mathrm{H}\right] \mathrm{PN} 200-110$ at $22^{\circ} \mathrm{C}$ for $45 \mathrm{~min}$. Nonspecific binding was determined in the presence of $2 \mu \mathrm{M}$ unlabelled $\mathrm{PN} 200-110$.

\section{Miscellaneous methods}

Oligodeoxynucleotide synthesis was run by standard protocol supplied by the manufacturer on an automated singlecolumn synthesizer. PCR were performed as in [14] and the amplified cDNA were subcloned and sequenced on both strands [30]. Cloning procedures, if not stated otherwise, were carried out as described [31]. Protein concentrations were determined according to [32].

\section{RESULTS}

\section{Tissue specific expression of calcium channel subunits}

The tissue-specific distribution of mRNA specific for the calcium channel $\alpha_{1}, \alpha_{2} / \delta, \beta$ and $\gamma$ subunits was analyzed by RNA-blot analysis of poly(A)-rich RNA from several rabbit tissues using subunit-specific antisense RNA probes. In Fig. 1 a, a probe derived from domains 3 and 4 of $\mathrm{CaCh} 2$ hybridized to a poly(A)-rich RNA species in skeletal muscle of $6.5 \mathrm{~kb}$, which is identical to the skeletal muscle $\alpha_{1}$ subunit mRNA described previously [9-11]. A less-abundant mRNA species, with an estimated size of about $8.9 \mathrm{~kb}$, is also present in skeletal muscle. In contrast, $8.9-\mathrm{kb}$, but not $6.5-\mathrm{kb}$, transcripts were detected in poly(A)-rich RNA from brain, heart, aorta, trachea and lung. In addition, weakly hybridizing transcripts of about $15.5 \mathrm{~kb}$ were observed in these tissues. The intensity of the $\alpha_{1}$ hybridization signals varied among the different tissues, being most intense in skeletal muscle and lung.

To investigate the expression of transcripts related to those encoding the lung and cardiac muscle $\alpha_{1}$ subunits, specific RNA probes derived from their 5 'nucleotide sequences were used (Fig. 1 b and c). For the cardiac-channel-specific probe, a prominent $8.9-\mathrm{kb}$ and a much weaker $15.5-\mathrm{kb}$ transcript were detected in poly(A)-rich RNA from cardiac muscle (Fig. 1 b). However, no signals were detected in other tissues, even after two weeks autoradiographic exposure (data not shown). The probe derived from the lung $\alpha_{1}$ sequence hybridized to a number of RNA species in all tissues, including $8.9-\mathrm{kb}$ and $15.5-\mathrm{kb}$ transcripts in brain, heart, aorta, trachea and lung (Fig. 1c).

The probe of the skeletal $\alpha_{2} / \delta$ subunit hybridized to an 8.0-kb transcript in poly(A)-rich RNA from each of the tissues examined (Fig. $1 \mathrm{~d}$ ). In addition, a weakly hybridizing $\alpha_{2}$ 7.0 -kb transcript was observed in these tissues. The $\beta$-subunitderived probe hybridized to three poly(A)-rich RNA species of skeletal muscle with estimated sizes of $1.6,1.9$ and $3.0 \mathrm{~kb}$. mRNA species of similar size to the $3.0-\mathrm{kb}$ species appear to be present in brain and aorta. A less-abundant mRNA population of about $4.8 \mathrm{~kb}$, which was detected only as a faint band after long autoradiographic exposure, is present in heart. The $\gamma$-subunit probe hybridized to a $1.3-\mathrm{kb}$ poly (A)-rich RNA species from skeletal muscle $[14,15]$. Weakly hybridizing $\gamma$ transcripts of $1.0 \mathrm{~kb}$ (heart), and $1.3 \mathrm{~kb}$ and $1.8 \mathrm{~kb}$ (aorta) were observed. In brain, a $1.5-\mathrm{kb}$ signal was clearly visible after 5 day autoradiographic exposure, but not after $16 \mathrm{~h}$ (compare Fig. 3B, d, lane 6, with Fig.1f, lane 2). No $\alpha_{1}-, \alpha_{2}$ $\delta$-, $\beta$ - and $\gamma$-specific hybridization was observed with poly(A)rich RNA and total RNA from HeLa cells, murine L-cells and Paramecium tetraurelia.

Characterization of tissue specific expression of $\alpha_{1}$ subunits by $P C R$. The Northern-blot experiments indicated that $\mathrm{CaCh} 2 \mathrm{~A}$ is expressed only in heart, whereas $\mathrm{CaCh} 2 \mathrm{~B}$ seems to be expressed in heart, brain, aorta, lung and trachea (Fig. $1 \mathrm{~b}$ and $\mathrm{c}$ ). To confirm the existence and differential expression of mRNA for type $\mathrm{CaCh} 2 \mathrm{~A}$ and $\mathrm{CaCh} 2 \mathrm{~B}$ by an independent method, $\mathrm{CaCh} 2 \mathrm{~A}$ - and $\mathrm{CaCh} 2 \mathrm{~B}$-specific sequences were amplified by two sets of PCR from heart, lung and trachea. This method has an important advantage over Northern-blot analysis of RNA in that the exact sequence expressed in a given tissue can be determined. The general location of the sequence spanned by the primers used (Table 2 ) is depicted as $\mathrm{a}, \mathrm{b}$ and $\mathrm{c}$ in Fig. $2 \mathrm{~A}$. These regions of the $\mathrm{CaCh} 2$ gene have been described as alternative splicing products [17]. Template cDNA were constructed with poly(A)-rich RNA from rabbit heart, lung and trachea using oligodeoxynucleotide primer 1 which covers a region which is conserved between the cardiac $(\mathrm{CaCh} 2 \mathrm{~A})$ and lung $(\mathrm{CaCh} 2 \mathrm{~B})$ isoforms. For PCR covering the amino-terminal region (site a) pairs of oligonucleotides were used, which were derived from the $5^{\prime}$ sequence of $\mathrm{CaCh} 2 \mathrm{~A}$ (primer 2) and $\mathrm{CaCh} 2 \mathrm{~B}$ (primer 4) and a region which is identical in both isoforms (primer 3 ). Clones amplified from cardiac cDNA with primers 2 and 3 had an identical sequence to that obtained by Mikami et al [16]. For example, the DNA sequence of rabbit clone 7 is $100 \%$ identical to that of the rabbit cardiac calcium channel (CaCh2A, Fig. 2B). However, using the same primer pair, but with cDNA from lung and trachea, did not lead to any specific amplification. In contrast, PCR initiated by primers 4 and 3 with cDNA from heart, lung and trachea yield specific amplification products in all cases. Sequencing by the dideoxy-chain-termination 
A

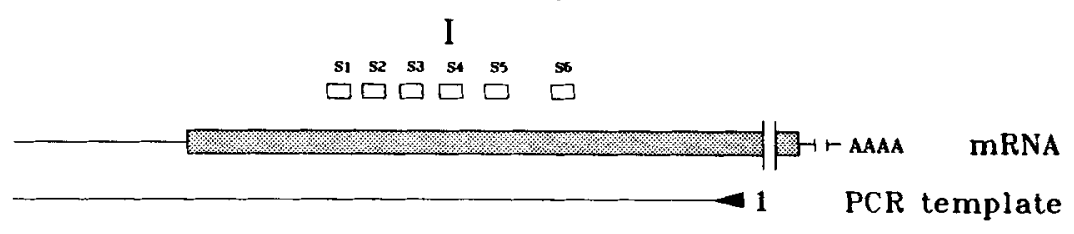

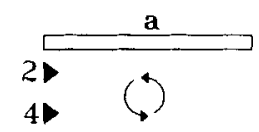

43

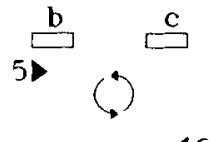

46 target sequences

specific primers

B

Aminoterminus (a)

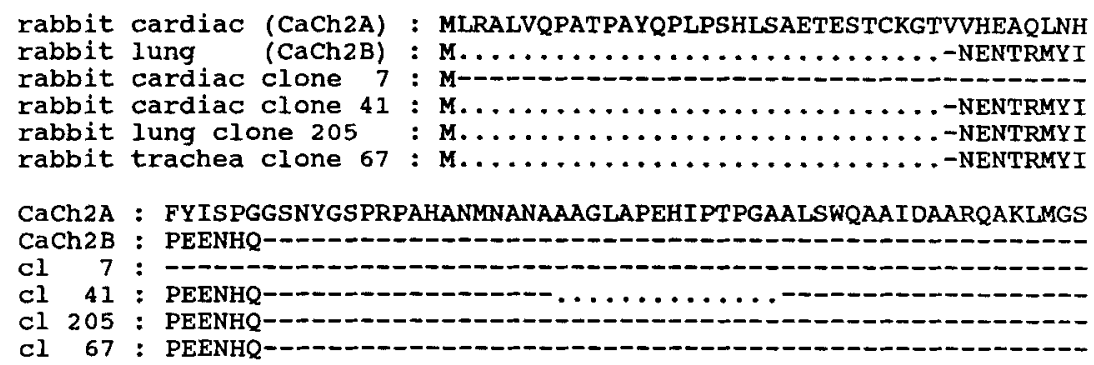

C

Segment IS6 (b) and consecutive region (c)

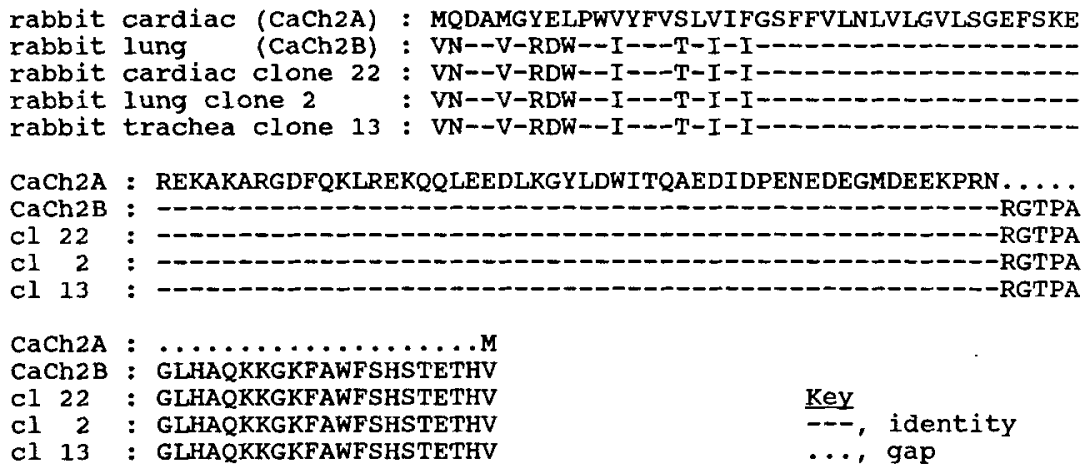

Fig. 2. Diagram of part of the general structure of $L$-type calcium channels ( $A$ ) and amino acid sequences of $P C R$ products ( $B, C$ ) obtained from first-strand cDNA derived from rabbit heart, lung and trachea. (A) A representation of part of the $\alpha_{1}$ subunit of L-type calcium channels showing relative positions of the transmembrane segments (S) $1-6$ of domain I. The hatched box represents the protein coding-region. Triangles indicate relative positions of oligodeoxynucleotide primers $1-6$ used for primer extension (1) and PCR (2-6). a $-\mathrm{c}$ Target sequences which are not identical in the $\alpha_{1}$ subunit cDNA cloned from rabbit heart [16] and lung [17]. (B, C) Results of PCR using specific primers derived from $\mathrm{CaCh} 2 \mathrm{~A}(2,3)$ and $\mathrm{CaCh} 2 \mathrm{~B}(3-6)$. The deduced amino acid sequences are compared with that of the rabbit cardiac muscle isoform $(\mathrm{CaCh} 2 \mathrm{~A})$

method revealed that the clone amplified from cardiac cDNA (rabbit cardiac clone 41) is identical to the sequence of $\mathrm{CaCh} 2 \mathrm{~B}$, except that it lacks 42 bp within the sequence conserved in $\mathrm{CaCh} 2 \mathrm{~A}$ and $\mathrm{CaCh} 2 \mathrm{~B}$. The sequences of the clones obtained with cDNA from lung (clone 205) and trachea (clone 67) were $100 \%$ identical to that of $\mathrm{CaCh} 2 \mathrm{~B}$.

For PCR covering sites $b$ and $c$, pairs of oligonucleotide primers were derived from the $5^{\prime}$ and $3^{\prime}$ ends of sites $b$ and $c$, respectively, of the $\mathrm{CaCh} 2 \mathrm{~B}$ sequence. DNA were amplified from heart, lung and trachea. Sequences of clones obtained from heart (rabbit cardiac clone 22), lung (clone 2) and trachea (clone 13) were $100 \%$ identical to that of $\mathrm{CaCh} 2 \mathrm{~B}$ (Fig. 2C).

Expression of calcium channel transcripts in $B C_{3} \mathrm{H} 1$ cells. The results of the nucleic acid hybridization studies indicated that mRNA of various $\alpha_{1}, \alpha_{2} / \delta, \beta$ and $\gamma$ subunits are coexpressed in each tissue, suggesting that all subunits may con- 
tribute to calcium channel function. In this case, their mRNA expression should be regulated in a coordinate manner. A model system to study this regulation is the clonal $\mathrm{BC}_{3} \mathrm{H} 1$ cell line. It is derived from a mouse brain tumor and possesses many properties characteristic of muscle [28]. In addition, differentiated, but not proliferating, $\mathrm{BC}_{3} \mathrm{H} 1$ cells express voltage-activated dihydropyridine-sensitive and dihydropyridineinsensitive calcium currents, whose electrophysiological properties are different from those found in smooth muscle, cardiac muscle and neurons and resemble best those found in skeletal muscle cells [33-35]. Accordingly, differentiated $\mathrm{BC}_{3} \mathrm{H} 1$ cells express calcium-channel-blocker-binding sites (Fig. 3A, lane D), whereas these sites are barely detectable in subconfluent, proliferating cells $(\mathrm{P} 1-\mathrm{P} 3)$. To determine the expression of the mRNA of the calcium channel proteins, total RNA and poly(A)-rich RNA was isolated from proliferating subconfluent and differentiated $\mathrm{BC}_{3} \mathrm{H} 1$ cells. As shown in Fig. 3B, a, $\alpha_{1}$ transcripts were barely detectable in proliferating cells (Fig. 3B,a, lanes 2-4). However, after switching subconfluent $\mathrm{BC}_{3} \mathrm{H} 1$ cells to serum-deprived medium there was a marked induction of a $6.5-\mathrm{kb}$ transcript (Fig. 3 B, a, lane 5). This $\alpha_{1}$ specific transcript was also induced when cells in growth medium reached confluence (data not shown). The size of this transcript is identical to that of the skeletal muscle $\alpha_{1}$ subunit (Fig. 3B, a, lane 1), but different to various transcripts observed in rabbit brain (Fig. $3 \mathrm{~B}$, a, lane 6). In addition, a $4.0-\mathrm{kb}$ transcript was observed in $\mathrm{BC}_{3} \mathrm{H} 1$ cells, which has been described previously [35] and has been attributed to nonspecific hybridization to the leading edge of $28 \mathrm{~S}$ ribosomal RNA. For the $\beta$ subunit, a $1.9-\mathrm{kb}$ transcript was detected in total RNA from differentiated, but not from proliferating, cells (Fig. 3B, b, lane 5), whereas no $\alpha_{2} / \delta$-specific transcripts were detectable (Fig. $3 \mathrm{~B}$, c, lanes $2-$ 5). In contrast, a transcript specific for the $\gamma$ subunit was detected in total RNA from each of the cells examined (Fig. 3B,d, lanes 2-5). The intensity of this signal increase being most prominent in differentiated cells. Its size is similar to that of the $\gamma$ transcript in skeletal muscle (Fig. $3 \mathrm{~B}, \mathrm{~d}$, lane 1), but smaller than that in brain (Fig. $3 \mathrm{~B}, \mathrm{~d}$, lane 6). Taken together, these results demonstrate, that $\alpha_{1}, \beta$ and $\gamma$ mRNA are expressed together in differentiated but not in proliferating $\mathrm{BC}_{3} \mathrm{H} 1$ cells, suggesting that expression of their mRNA, but not of $\alpha_{2} / \delta$ mRNA, is regulated in a coordinate manner.

\section{DISCUSSION}

In this investigation, the expression of the calcium channel $\alpha_{1}, \alpha_{2} / \delta, \beta$ and $\gamma$ mRNA was studied in various rabbit tissues and $\mathrm{BC}_{3} \mathrm{H} 1$ cells by Northern-blot analysis and PCR. It is shown that $\alpha_{1}, \alpha_{2} / \delta$-, $\beta$ - and $\gamma$-specific transcripts exist together in skeletal muscle, brain, heart and aorta, (b) that alternate splicing products for the $\mathrm{CaCh} 2$ gene are tissuespecifically expressed and (c) that in $\mathrm{BC}_{3} \mathrm{H} 1$ cells induction of a functional receptor for calcium channel blockers parallels the expression of $\alpha_{1}-, \beta$ - and $\gamma$-specific mRNA, suggesting that their expression is developmentally regulated. At least three $\alpha_{1}$ specific transcripts exist with estimated sizes of about 6.5, 8.9 and $15.5 \mathrm{~kb}$. The $6.5-\mathrm{kb}$ transcript represents the mRNA of the skeletal muscle calcium channel $\alpha_{1}$ subunit [9-11]. In the nomenclature used here, this transcript is derived from gene 1 (CaCh1) and predominantly expressed in skeletal muscle (Fig 1 a, lane 1), although expression in other tissues has been described $[10,18]$. The size of the second transcript which is present in skeletal muscle, brain, heart, aorta, trachea

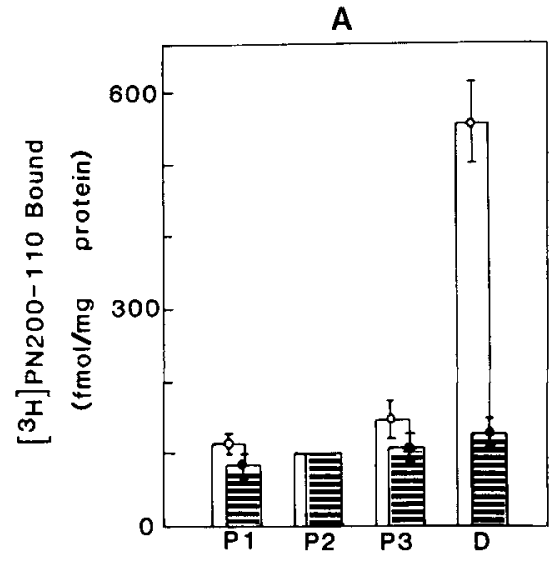

B

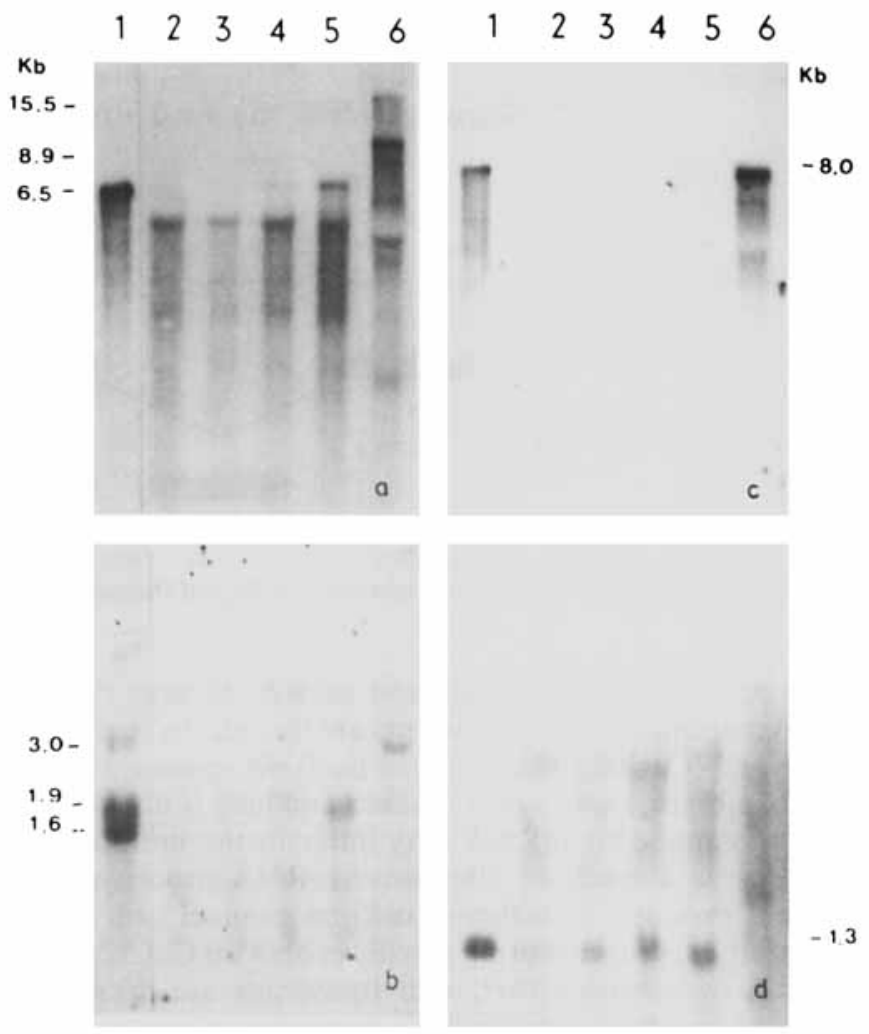

Fig. 3. Induction of dihydropyridine binding sites (A) and calcium channel subunits mRNAs (B). (A) Development of $\left[{ }^{3} \mathrm{H}\right] \mathrm{PN} 200-110-$ binding site density in proliferating (P1 - P3) and differentiated (D) $\mathrm{BC}_{3} \mathrm{H} 1$ cells. Open and hatched columns represent total and nonspecific binding, respectively. Bars indicate mean \pm SEM from six different experiments performed in triplicate. (B) Samples of $2 \mu \mathrm{g}$ poly(A)-rich RNA from rabbit skeletal muscle (lane 1) and brain (lane 6), $5 \mu \mathrm{g}$ of poly(A)-rich RNA (a, c) and $20 \mu \mathrm{g}$ total RNA b, d) from proliferating (lanes $2-4$ ) and differentiated (lane 5) $\mathrm{BC}_{3} \mathrm{H} 1$ cells, respectively, were electrophoresed on $1 \%$ agarose gels. Autoradiographic exposure was $16 \mathrm{~h}$ (a, lanes 1 and 6 ; b, lanes 1 and 6; d, lane 1), 5 days (a, lanes 2-5; b, lanes 2-5; c, d, lanes 2-6) at $-70^{\circ} \mathrm{C}$ with an intensifying screen. The RNA probes used were specific for the skeletal muscle $\alpha_{1}, \beta, \alpha_{2} / \delta$ and $\gamma$ subunits $(\mathrm{a}-\mathrm{d}$, respectively). The specific activities of the four RNA probes used were $0.7-2.6 \times 10^{9} \mathrm{dpm} / \mu \mathrm{g}$.

and lung is consistent with the size of the cloned cDNA of the $\alpha_{1}$ subunits from heart (7036 nucleotides) [16] and lung (7374 nucleotides) [17], considering that both cDNA lack conven- 
Aminoterminus (a)

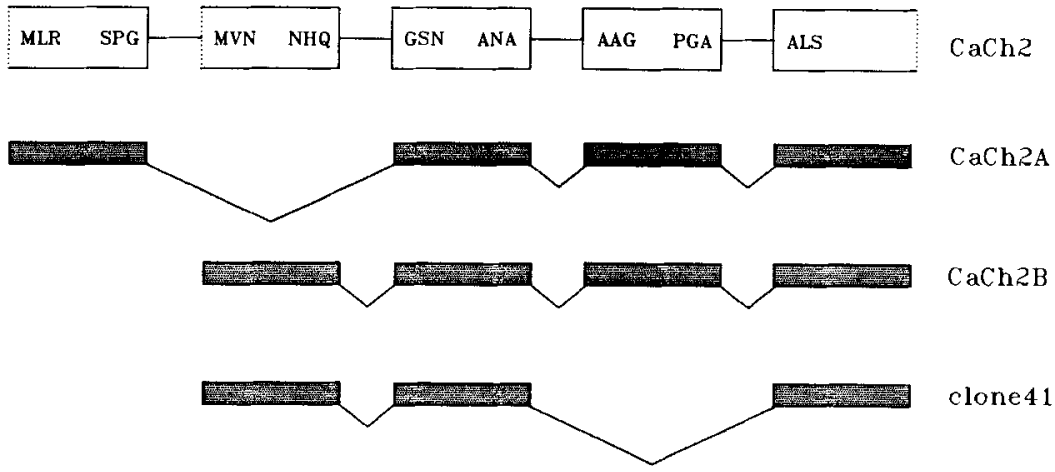

B

Segment IS6 (b) and consecutive region (c)

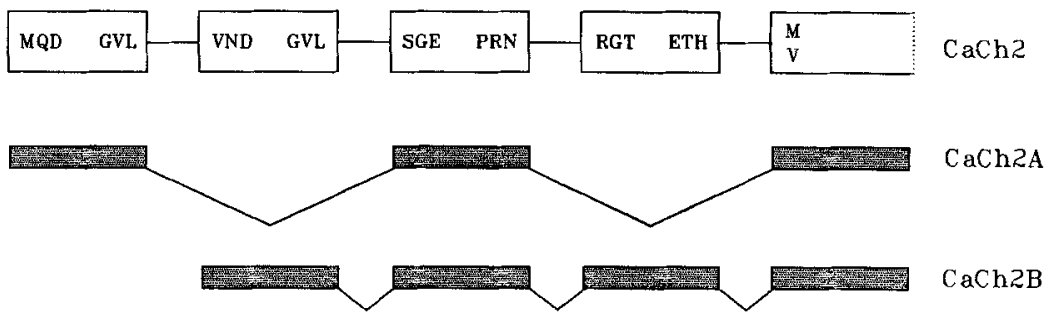

Fig. 4. Models of alternate splicing events that give rise to nucleotide sequences of CaCh2 encoding different amino-termini ( $A$ ), IS6 segments and consecutive regions $(B)$. Boxes represent exons and include amino acids encoded at their $5^{\prime}$ - and $3^{\prime}$ ends

tional polyadenylation signals and poly(A) tails at their $3^{\prime}$ ends. Accordingly, these transcripts are thought to be derived from gene $2(\mathrm{CaCh} 2)$. The nature of the RNA species of about $15.5 \mathrm{~kb}$ in brain, heart, aorta, trachea and lung is not known. These less-abundant mRNA may differ in the untranslated sequences as a result of alternative mRNA processing, or represent products of different calcium channel genes. Hybridization experiments using specific probes for $\mathrm{CaCh} 2 \mathrm{~A}$ and $\mathrm{CaCh} 2 \mathrm{~B}$, demonstrate that both transcripts are present in heart whereas only the $\mathrm{CaCh} 2 \mathrm{~B}$ transcript is expressed in brain, heart, aorta, trachea and lung. This tissue distribution suggests that the $\mathrm{CaCh} 2 \mathrm{~A}$ transcript is exclusively expressed in cardiac myocytes, whereas the $\mathrm{CaCh} 2 \mathrm{~B}$ transcript might be present in airway and vascular smooth muscle cells which are present in brain, heart, aorta, trachea and lung. The skeletal muscle differs from the other tissues since it contains $\alpha_{1}$ specific transcripts of $8.9 \mathrm{~kb}$, although no hybridization signals of this size were found with the $\mathrm{CaCh} 2 \mathrm{~A}-$ and $\mathrm{CaCh} 2 \mathrm{~B}-$ specific probes. This may be due either to the lower vascularisation of this tissue or to the presence of additional splice variants of the $\mathrm{CaCh} 2$ gene.

Further evidence for the presence of alternate splice products of the $\mathrm{CaCh} 2$ gene comes from PCR covering the 5' nucleotide sequence encoding the amino-terminus (Fig. 2B, site a) and the membrane spanning region 6 of domain $\mathrm{I}$ (Fig. 2C, site b), which are different in the $\mathrm{CaCh} 2 \mathrm{~A}$ and $\mathrm{CaCh} 2 \mathrm{~B}$ sequences [17] and an insertion within the predicted cytoplasmic linker between domains I and II (Fig. 2C, site c) which is present in $\mathrm{CaCh} 2 \mathrm{~B}$, but not in $\mathrm{CaCh} 2 \mathrm{~A}$ [17]. The amplified sequences covering site a in Fig. 2B are identical with either the $\mathrm{CaCh} 2 \mathrm{~A}$ or the $\mathrm{CaCh} 2 \mathrm{~B}$ sequence. However, the $\mathrm{CaCh} 2 \mathrm{~A}$ sequence is only amplified from heart, whereas the $\mathrm{CaCh} 2 \mathrm{~B}$ sequence is not only present in lung but also in trachea and heart. This tissue-specific expression of alternate splicing products of $\mathrm{CaCh} 2$ is in agreement with the results of the Northern-blot experiment shown in Fig. $1 \mathrm{~b}$ and c. In addition, a third splice variant was identified (clone 41) which is identical to $\mathrm{CaCh} 2 \mathrm{~B}$ except that it lacks $42 \mathrm{bp}$ within the sequences that are identical in $\mathrm{CaCh} 2 \mathrm{~A}$ and $\mathrm{Cach} 2 \mathrm{~B}$. The amplified sequences covering predicted transmembrane segment 6 of domain I (Fig. 2C, site b) and the consecutive region (site c) are identical with the $\mathrm{CaCh} 2 \mathrm{~B}$ subtype. Fig. 4 illustrates models for the formation of the alternatively spliced forms of $\mathrm{CaCh} 2$ within site $\mathrm{a}$, and sites $\mathrm{b}$ and $\mathrm{c}$. Both models assume the existence of three alternatively spliced exons and one intervening sequence of which two exons are of the alternate type and the third is either used or skipped. Although this kind of analysis was not extended to other regions of the $\mathrm{CaCh} 2$ sequence, there is the possibility that additional alternate splice products exist. In fact, another splice variant has been identified in partial $\mathrm{CaCh} 2$-derived cDNA clones covering the consecutive region of transmembrane segment 3 of domain IV [18]. The presence of regions of $\mathrm{CaCh} 2$ that are alternative splice products make it necessary to examine carefully whether the cDNA segments spliced together in vitro to reconstruct full-length cDNA do indeed coexist in vivo on the same mRNA molecule. In addition, it will be important not only to define which type of channel variant is expressed, but 
also what, if any, functional correlate may be established between splice variants and type of current. The functions of the amino-terminus and of segment 6 of domain I described here have not been determined. However, in current topographical models the amino-terminus is localized intracellularly and cytoplasmic elements have been shown to be involved in both activation and inactivation gating in voltage-activated potassium [36] and sodium channels [37].

$\alpha_{2}$-specific transcripts of $8.0 \mathrm{~kb}$ were detected in poly(A)rich RNA from each of the tissues examined. In addition, weakly hybridizing $\alpha_{2} 7.0-\mathrm{kb}$ transcripts were observed. The size of the cloned $\alpha_{2}$ cDNA (about $7.8 \mathrm{~kb}$ including a $4.5-\mathrm{kb}$ untranslated sequence) $[10,16]$, is consistent with an $8.0-\mathrm{kb}$ $\alpha_{2}$ mRNA, whereas the 7.0-kb $\alpha_{2}$ mRNA may differ in the $3^{\prime}$ untranslated sequence. Three $\beta$-subunit-specific transcripts exist in skeletal muscle, which may all differ in the coding and noncoding sequences as a result of alternative mRNA processing. The size of the $1.9-\mathrm{kb}$ species is consistent with the size of the cloned cDNA (1835 nucleotides) [13]. Splice variants of the same $\beta$-subunit gene appear to be present in brain and aorta, whereas heart contains a faintly hybridizing transcript of $4.8 \mathrm{~kb}$ which might be derived from a second $\beta$ like gene. $\gamma$-subunit-specific transcripts of various sizes were observed in skeletal muscle, brain, heart and aorta. The lack of $\beta$ - and $\gamma$-specific hybridization signals from lung and trachea may be due either to the lower concentration of $\beta$ - and $\gamma$-subunit mRNA in these tissues, or to the presence of subunits with considerably different nucleotide sequences encoded by separate genes.

Apparently splice variants of the genes for the $\alpha_{1}, \alpha_{2} / \delta, \beta$ and $\gamma$ subunits coexist in tissues which contain L-type calcium channcls. The correlation of their expression with that of functional channels was examined in the $\mathrm{BC}_{3} \mathrm{H} 1$ cell line, which has been used as a model for studying muscle cell differentiation and the regulation of muscle-related proteins. Removal of growth factors from the culture medium or allowing cultures to reach confluence induces $\mathrm{BC}_{3} \mathrm{H} 1$ cells to differentiate and to accumulate muscle-specific gene products [38]. In addition, it has been shown that differentiated $\mathrm{BC}_{3} \mathrm{H} 1$ cells express skeletal muscle voltage-activated calcium channels [33-35], and partial cDNA clones isolated from $\mathrm{BC}_{3} \mathrm{H} 1$ cells reveal a high degree of sequence similanty to the rabbit skeletal muscle $\alpha_{1}$ nucleotide sequence [18]. In agreement with these results, the experiments shown in Fig. 3 indicate that $\mathrm{BC}_{3} \mathrm{H} 1$ express a skeletal-muscle-type $\alpha_{1}$ subunit and that the time course for induction of a skeletal-muscle-type $\alpha_{1^{-}}, \beta$ - and $\gamma$-subunit mRNA is similar to that reported for the induction of the contractile protein mRNA and parallels the appearance of dihydropyridine-binding sites. Obviously, the expression of calcium channel $\alpha_{1}, \beta$ and $\gamma$ subunits, but not of the $\alpha_{2} / \delta$ subunit, is controlled by a common regulatory mechanism in these cells and contributes to the formation of a dihydropyridine-sensitive calcium channel. The availability, now, of molecular probes for the expression of the various calcium channel subunits should allow further dissection of channel components regulating calcium channel function and modulation.

We thank T. Tanabe and S. Numa for kindly providing pSPCA1, R. Nagel for expert technical assistance and H. Siepmann for the graphical work. This work was supported by Deutsche Forschungsgemeinschaft, Thyssen Stiftung and Fond der Chemischen Industrie.

\section{REFERENCES}

1. Reuter, H. (1983) Nature 301, 969-974.

2. Tsien, R. W., Bean, B. P., Hess, P., Lansman, J. B., Nilius, B. \& Nowycky, M. C. (1986) J. Mol. Cell. Cardiol. 18, $691-710$.

3. Trautwein, W. \& Hescheler, J. (1990) Annu. Rev. Physiol. 52, $257-274$.

4. Brown, A. M. \& Birnbaumer, L. (1990) Annu. Rev. Physiol. 52, $197-213$.

5. Hofmann, F., Flockerzi, V., Nastainezyk, W., Ruth, P. \& Schneider, T. (1990) Curr. Top. Cell. Regul. 31, 225-239.

6. Glossmann, H. \& Striessnig, J. (1988) Vitam. and Horm. 44, 154 327.

7. Catterall, W. A., Seagar, M. J. \& Takahashi, M. (1988) J. Biol. Chem. 263, 3535-3538.

8. Campbell, K. P., Leung, A. T. \& Sharp, A. H. (1988) Trends Neurosci. $11,425-430$.

9. Tanabe, T., Takeshima, H., Mikami, A., Flockerzi, V., Takahashi, H., Kangawa, K., Kojima, M., Matsuo, H., Hirose, T. \& Numa, S. (1987) Nature 328, 313-318.

10. Ellis, S. B., Williams, M. E., Ways, N. R., Brenner, R., Sharp, A. H., Leung, A. T., Campbell, K. P., McKenna, E., Koch, W. J., Hui, A., Schwartz, A. \& Harpold, M. M. (1988) Science 24I, $1661-1664$.

11. Perez-Reyes, E., Kim, H. S., Lacerda, A. E., Horne, W., Wei, X., Rampe, D., Campbell, K. P., Brown, A. M. \& Birnbaumer, L. (1989) Nature 340, 233-236.

12. De Jongh, K. S., Warner, C. \& Catterall, W.A. (1990) J. Biol. Chem. 265, 14738-14741.

13. Ruth, P., Röhrkasten, A., Biel, M., Bosse, E., Regulla, S., Meyer, H. E., Flockerzi, V. \& Hofmann, F. (1989) Science 245, $1115-$ 1118.

14. Bosse, E., Regulla, S., Biel, M., Ruth, P., Meyer, H. E., Flockerzi, V. \& Hofmann, F. (1990) FEBS Lett. 267, $153-156$.

15. Jay, S. D., Ellis, S. B., McCue, A. F., Williams, M. E., Vedvick, T. S., Harpold, M. M. \& Campbell, K. P. (1990) Science 248, $490-491$.

16. Mikami, A., Imoto, K., Tanabe, T., Niidome, T., Mori, Y., Takeshima, H., Narumiya, S. \& Numa, S. (1989) Nature 340, $230-233$.

17. Biel, M., Ruth, P., Bosse, E., Hullin, R., Stühmer, W., Flockerzi, V. \& Hofmann, F. (1990) FEBS Lett. 269, 409-412.

18. Perez-Reyes, E., Wei, X., Castellano, A. \& Birnbaumer, L. (1990) J. Biol. Chem. 265, 20430-20436.

19. Koch, W. J., Hui, A., Shull, G., Ellinor, P. \& Schwartz, A. (1989) FEBS Lett. 250, 386-388.

20. Snutch, T. P., Leonard, J. P., Giibert, M. M. \& Lester, H.A. (1990) Proc. Natl Acad. Sci. USA 87, 3391-3395.

21. Koch, W. J., Ellinor, P. T. \& Schwartz, A. (1990) J. Biol. Chem. $265,17786-17791$.

22. Huang, P., Temizer, D. \& Quertermous, T. (1990) FEBS Lett. $274,207-213$.

23. Grabner, M., Friedrich, U., Knaus, H.-G., Striessnig, J., Scheffauer, F., Staudinger, R., Koch, W. J., Schwartz, A. \& Glossmann, H. (1991) Proc. Natl Sci. USA 88, 727 - 731.

24. Tanabe, T., Beam, K. G., Powell, J. A. \& Numa, S. (1988) Nature $366,134-139$.

25. Kim, H. S., Wei, X., Ruth, P., Perez-Reyes, E., Flockerzi, V., Hofmann, F. \& Birnbaumer, L. (1990) J. Biol. Chem. 265, 11858-11863.

26. Melton, D. A., Krieg, P. A., Rebagliati, M. R., Maniatis, T. Sinn, K. \& Green, M. R. (1984) Nucleic Acids Res. 12, 70357056.

27. Thomas, P. S. (1980) Proc. Natl Acad. Sci. USA 77, 5201-5205.

28. Olson, E. N., Caldwell, K. L., Gordon, J. I. \& Glaser, L. (1983) J. Biol. Chem. 258, 2644-2652.

29. Ruth, P., Flockerzi, V., v. Nettelbladt, E., Oeken, J. \& Hofmann, F. (1985) Eur. J. Biochem. 150, 313-322.

30. Sanger, F., Nicklen, S. \& Coulson, A.B. (1977) Proc. Natl. Acad. Sci.USA 74, 5463-5467.

31. Sambrook, J., Fritsch, E. F. \& Maniatis, T. (1989) Molecular cloning: a laboratory manual, Cold Spring Harbor Laboratory, Cold Spring Harbor, NY. 
32. Smith P. K., Krohn, R. I., Hermanson, G. T., Mallia, H. K., Gartner, F. H., Provenzano, M. D., Fujimoto, E. K., Goeke, N. H., Olson, B. J. \& Klenk, D. C. (1985) Anal. Biochem. 150, $76-85$.

33. Caffrey, J. M., Brown, A. M. \& Schneider, M. D. (1987) Science $236,570-574$.

34. Rampe, D. E., Caffrey, J. M., Schneider, M. D. \& Brown, A. M. (1988) Biochem. Biophys. Res. Commun. 152, 769-775.
35. Shih, H.-T., Wathen, M. S., Marshall, H. B., Caffrey, J. M. \& Schneider, M.D. (1990) J. Clin. Invest. 85, $781-789$.

36. Hoshi, T., Zagotta, W. N. \& Aldrich, R. W. (1990) Science 250, 533-539.

37. Stühmer, W., Conti, F., Suzuki, H., Wang, X., Noda, M., Yahagi, N., Kubo, H. \& Numa, S. (1989) Nature 339, 597-603.

38. Schubert, D., Harris, A. J., Devine, C. E. \& Heinemann, S. (1974) J. Cell. Biol. 61, 398-413. 